\title{
The impact of risk factors on South African consumers' attitude towards online shopping
}

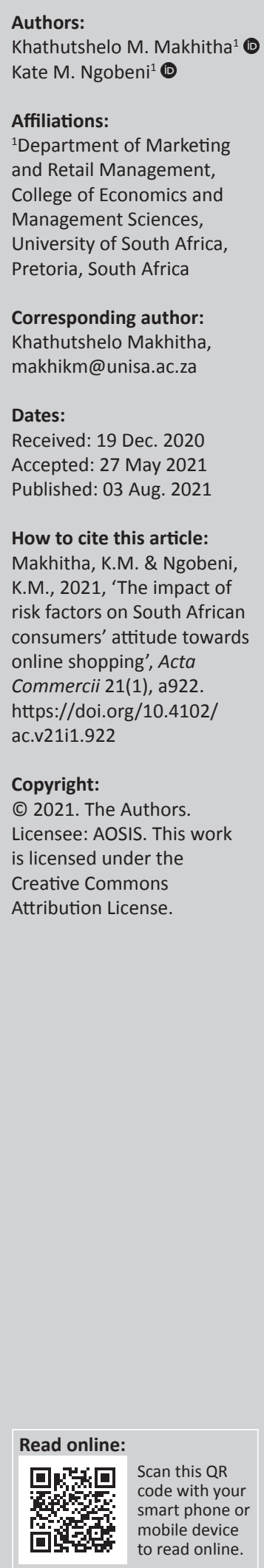

Orientation: The advances in technology have resulted in an increasing number of people choosing to shop online, globally. Despite the growing number of those shopping online and online retailers, most customers continue to avoid shopping online. This could be because of risks inherent in online shopping that have resulted in some consumers opting not to shop online.

Research purpose: The main aim of the research study is to identify the risks influencing consumers' attitude towards online purchases.

Motivation for the study: The study was driven by the need to determine the risks associated with online shopping that influence whether consumers will shop online or not.

Research design, approach and method: A survey, using the non-probability convenience sampling method, was used to reach respondents (207 consumers in South Africa who visited two shopping malls) in Gauteng, South Africa. Data were collected from consumers at the two shopping malls from March 2019 to April 2019. Structural equation modelling (SEM) was used to test the conceptual model for the study.

Main findings: The results showed that product risk and privacy risk influence consumer attitude in online shopping positively and that delivery risk does not to have a great influence on attitude towards online shopping. The attitude towards online shopping was also found to positively influence their intention to shop online.

Practical/managerial implications: The practical implications for this study would be that retail owners and marketers would understand and manage product and privacy as risks that inhibit consumers from shopping online. Retailers should formulate appropriate marketing and retail strategies that address these risks to change consumers' perceptions about online shopping and reduce the level of risks related to online shopping.

Contribution/value-add: Marketing and retail strategies should include strategies on how product risk and privacy risks will be managed and reduced to ensure they do not influence consumer's attitude against online shopping.

Keywords: online shopping; purchase intention; risk factors; attitude, consumer behaviour.

\section{Introduction}

Online shopping has been an increasing trend worldwide, especially in countries with a welldeveloped infrastructure for online marketing activities. Online shopping involves purchasing goods and services over the internet (Malapane 2019:1). Consumers can now conveniently purchase products from anywhere, at any time (Arora \& Sahney 2018:1040), with an abundance of information. Given the benefits of online shopping, online transactions' high cart abandonment rates remain a concern (Statista 2020). This is because consumers often prefer to shop at physical retailers because of the ability to touch and feel products physically, instant possession, online distrust and the perceived risk associated with online purchases (Arora \& Sahney 2018:1040). Because of these concerns, online shopping is used to make price and product feature comparisons; however, the decision and actual purchases are made in store, after the physical evaluation (Wolny \& Charoensuksai 2014:324). This challenge presents an opportunity for online retailers and marketing practitioners to evaluate further the impact that perceived risk has on online buying behaviour and to comprehend online shopping through consumers' eyes. This is supported by Yang, Sarathy and Lee (2016:75), who stated that future research should take a more consumer-centric approach and try to understand better the impact of online shopping risk factors on consumers' purchasing behaviour.

Perceived risk factors that affect online shopping behaviour have been identified in previous studies (Bhatti, Saad \& Gbadebo 2018; Orubu 2016; Tandon, Kiran \& Sah 2018). However, future researchers 
should focus on other potential online shopping risk factors that could have an impact on consumers' attitudes and their purchasing behaviour (Hong, Zulkiffli \& Hamsani 2016:20). Bhatti et al. (2018:8-9) further suggested that future researchers should investigate online shopping adoption, purchase intention and behaviour in relation to the perceived risks in developing and developed countries. To ensure universal applicability, the impact of risk factors on consumers' attitudes and intention to purchase online should be examined in other environments and segments (Marza, Idris \& Arbor 2019:594).

The advent of online shopping has evoked some concerns for consumers, including product quality assurance, insufficient information disclosure, security of payment methods and private information vulnerability (Ariff et al. 2014:309). These challenges have evolved because of online retailers' lack of understanding of the main risk factors influencing consumers' attitude and online shopping behaviour in South Africa. Moreover, limited research was performed regarding the perceived risk factors influencing consumers' attitudes and the effect of attitude on consumers' online shopping intention. Investigating this is important, as it will help marketing practitioners and online retailers to understand better how they can improve their online sales. It will also provide online retailers with useful information to formulate strategies and to help curb the risks faced in the online shopping environment. This study was conducted to achieve the following three objectives:

- To determine perceived risk factors affecting consumers' attitude towards online shopping intentions in South Africa.

- To determine the influence that perceived risk factors have on attitude towards online shopping in South Africa.

- To determine the effect of online shoppers' attitude towards their intention to shop online in South Africa.

\section{Literature review}

\section{The South Africa online shopping development}

The South African e-commerce market is composed of 19.9 million users, with 4.9 million more anticipated in 2021 (Statista 2018). Currently, the market contributes $1 \%$ in value of the total retail sector, indicating an exponential growth opportunity (export.gov 2018). E-commerce is expanding at a rapid pace in the South African retail industry, especially in remote rural areas where traditional distribution channels are extremely expensive for retailers to reach consumers, which increase the cost of purchase for consumers (export. gov 2018). The shopping behaviour of South African consumers is also changing, with many consumers now doing research online before completing the transaction instore, whilst others do research in the store, but make the actual purchase online (Smith 2020).

According to Businesstech (2018), the South African online retail business is being reshaped by mobile e-commerce (m-commerce). This is driven by the proliferation of smartphones, improvements in network services (export. gov 2018; Payfast 2019) and the growing demand for flexibility and accessibility (Itnewsafrica 2017). Ease of use, convenience and instantaneous purchases have been identified as important determinants for satisfying South African consumers' needs and maintaining customer loyalty online (Itnewsafrica 2017). This has led Visa to realise that it must facilitate consumers' online purchasing process by implementing secure and trustworthy payment systems, which make it convenient to shop online (Smith 2020). However, online consumers in South Africa are still sceptical about shopping online, because of perceived risks, such as financial loss because of fraudulent retailers, product nondelivery, risk to privacy and the lack of product evaluation before the purchase (Malapane 2019:1, 5).

\section{Risk as a factor influencing online purchasing intentions}

Understanding consumers' perceptions of risk in online shopping is an important factor because it affects consumers' buying decisions in an online shopping environment. This suggests that if the risk is perceived to be high, consumers are less likely to buy a product online (Rosillo-Díaz, BlancoEncomienda \& Crespo-Almendros 2019:152). 'Perceived risk is referred to as consumers' perception of the uncertainty and adverse consequences of engaging in a purchase activity' (Pathak \& Pathak 2017:33). Previous studies have examined the influence of perceived risks on consumers' online shopping intentions, with some findings indicating that perceived risk has no effect on consumers' online shopping intentions (Bhatti et al. 2018:7-8). Other researches, on the other hand, indicate that consumers' perceptions of risk have no effect on their purchase decisions online (Lin et al. 2019:1198), which indicates that the effect of perceived risks on consumers' online shopping intention differs across consumers. The effect of perceived risks on consumers' online shopping intention also differs across types of risks (Nawi et al. 2019:9). There are various types of risks that serve as deterrents to conducting online transactions. The risk factors that affect consumers' online shopping behaviour are depicted (Table 1).

Previous studies have identified product risk (Masoud 2013:76; Orubu 2016:14), delivery risk (Masoud 2013:76; Tanadi et al. 2015:226) and security and privacy risk (Masoud 2013:76) as the factors that have most impact in online shopping behaviour. Given that these are the most important factors affecting consumers' online buying decisions, this study examines the impact of product risk, delivery risk, privacy risk and security risk on South African consumers' attitudes and, consequently, their online shopping intentions as depicted in Figure 1.

\section{Product risk}

Consumers experience difficulties in evaluating the quality of products online, as they must rely on limited information and images to make a purchase decision. Product risk is primarily caused by the incapability to inspect products thoroughly prior to purchase by touching, smelling and 
TABLE 1: Summary of studies about risk factors in online shopping.

\begin{tabular}{|c|c|}
\hline Risk factors & Authors \\
\hline Product risk & $\begin{array}{l}\text { Bhatti et al. (2018); Hong et al. (2016); Masoud (2013); Orubu } \\
\text { (2016); Pappas (2016); Pi and Sangruang (2011) }\end{array}$ \\
\hline Delivery risk & $\begin{array}{l}\text { Ariff et al. (2014); Hong et al. (2016); Masoud (2013); Tanadi, } \\
\text { Samadi and Gharleghi (2015) }\end{array}$ \\
\hline Time risk & Forsythe and Shi (2003); Pi and Sangruang (2011) \\
\hline Privacy risk & $\begin{array}{l}\text { Forsythe and Shi (2003); Hsu and Luan (2017); Jun and Jaafar } \\
\text { (2011); Orubu (2016) }\end{array}$ \\
\hline Security risk & $\begin{array}{l}\text { Ariff et al. (2014); Jun and Jaafar (2011); Keisidou, Sarigiannidis } \\
\text { and Maditinos (2011); Masoud (2013); Pappas (2016) }\end{array}$ \\
\hline Financial risk & $\begin{array}{l}\text { Ariff et al. (2014); Hsu and Luan (2017); Masoud (2013); Pi and } \\
\text { Sangruang (2011) }\end{array}$ \\
\hline Psychological risk & Ariff et al. (2014); Pi and Sangruang (2011) \\
\hline Social risk & Pi and Sangruang (2011); Thakur and Srivastava (2015) \\
\hline Physical risk & Pi and Sangruang (2011) \\
\hline Convenience risk & Bhatti et al. (2018); Pi and Sangruang (2011) \\
\hline
\end{tabular}

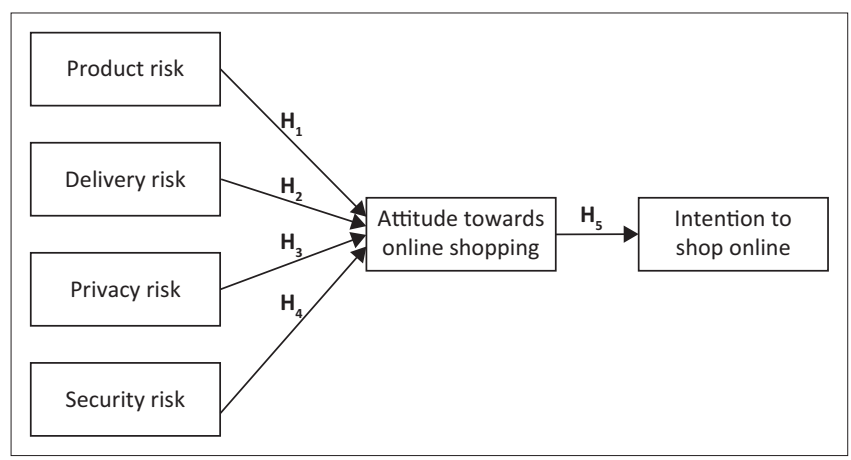

FIGURE 1: Conceptual model development.

feeling them (Ariff et al. 2014:3). Therefore, consumers perceive an elevated risk, because of the lack of a physical sense. According to Ariff et al. (2014:313), product risk is regarded as the risk of loss suffered by consumers should the product fall short of their expectations. This suggests that product risk is closely linked to the product's performance, relative to the consumers' expectation (Tandon et al. 2018:68). Consumers who want to purchase products online face a significant deterrent in the form of product risk (AghekyanSimonian et al. 2012:329). According to Bhatti et al. (2018:7-8), attitude has a significant moderating influence on product risk and online shopping behaviour. Consumers' attitude towards online shopping is negatively influenced by product risk (Ariff et al. 2014:7). Furthermore, consumers' attitude towards their online shopping intentions was found to be influenced more by product risk than by delivery risk (Hong et al. 2016:18). Therefore, the first hypothesis was formulated as follows:

$\mathbf{H}_{1}$ : Product risk has a significant influence on consumers' attitude.

\section{Delivery risk}

Consumers, who purchase products online, are generally concerned with the product's delivery. Delivery risks include the product being damaged whilst in transit, the product being delivered to a wrong address or even a delay in delivery. Delivery risk is a prevalent factor that influences online shopping behaviour of consumers (Tanadi et al. 2015:226). Delivery risk is defined as consumers' concerns about products not being delivered on time, product loss or damaged during transit (Ariff et al. 2014:3; Tanadi et al. 2015:227). Previous researchers have found several conflicting results regarding delivery risk. According to Masoud (2013:83), consumers' online purchasing intentions are not affected by delivery risk. However, consumers' attitude towards online purchasing intent has been shown to be negatively influenced by delivery risk (Hong et al. 2016:18). Moreover, Tanadi et al. (2015:227) reported that consumers' attitude towards online purchases is significantly influenced by delivery risk. Subsequently, the following hypothesis was formulated:

$\mathbf{H}_{2}$ : Delivery risk has a significant influence on consumers' attitude.

\section{Privacy risk}

In this regard, consumers avoid purchasing products online to avoid sharing personal information online and consumers cannot verify the retailers' credibility before purchasing especially in instances where the reputation of the retailer is unknown. Privacy concerns become prevalent, especially during the check-out process, which leads to consumers aborting their shopping carts (KukarKinney \& Close 2010:244). Having to share personal information on online payment systems leads to consumers feeling uneasy and vulnerable (Tanadi et al. 2015:228). The possibility of retailers misusing consumers' personal information discourages consumers from purchasing online (Thakur \& Srivastava 2015:153). Privacy risk is the possibility of losing sensitive information and becoming vulnerable to fraudulent activity in an online environment (Fortes \& Rita 2016:168).

Several factors affect consumers' online shopping behaviour, including privacy and security risks (Farhana et al. 2017 :225). Privacy risk has been identified as one of the most common factors preventing consumers from successfully completing online purchases that require digital wallets (Fortes \& Rita 2016:168). Furthermore, Orubu (2016:17) discovered that consumers' attitude towards online shopping is significantly influenced by privacy risk.

As a result, the following hypotheses were developed:

$\mathbf{H}_{3}$ : Privacy risk has a significant influence on consumers' attitude.

\section{Security risk}

Dai and Chen (2015:44) defined security as involving consumers' concern about information safety regarding the confidentiality, integrity and authentication of such information. Security risk is the possibility of financial loss when transacting online (Thakur \& Srivastava 2015:153). According to Ariffin, Mohan and Goh (2018:322), the most significant factor influencing consumers' online shopping behaviour is security risk. Jun and Jaafar (2011:122) established a correlation between consumers' attitude towards online shopping and their perception of security risks. This was confirmed by Keisidou et al. (2011:31) 
and Dai and Chen (2015:51), who found that consumers' attitude towards online shopping is influenced by perceived security risk although the influence was found to be negative by Ariffin et al. (2018:322). On the contrary, Tandon et al. (2018:82) found security to have no significant influence in online shopping. The fourth hypothesis was formulated as follows:

$\mathbf{H}_{4}$ : Security risk has a significant influence on consumers' attitude.

\section{Risk as a factor influencing attitude and online shopping intentions}

Consumers' perceived risk in online shopping context has an influence on purchase intention, indirectly, through attitude (Chang \& Wu 2012:387), suggesting that, if the perceived risk is high, then consumers will have a negative attitude and, therefore, their intention to purchase will be reduced (Chang \& Wu 2012:393).

Arora and Rahul (2018) examined the key factors of perceived risk that influence online shopping and found perceived risk not to have a substantial influence on the attitude of women in India (Arora \& Rahul 2018:108). This was supported by previous studies that found perceived risk has no significant effect towards online shopping (Bhatti et al. 2018:7-8; Marza et al. 2019:591).

In contrast, a study by Hsu and Luan (2017) revealed that perceived risk has an impact on attitudes. Attitude was found to have an impact on purchasing intent when it comes to online shopping platforms (Hsu \& Luan 2017:27). This was supported by Yang et al. (2016:74) who found a significant relationship between perceived risk and consumer attitude towards online shopping. Consequently, the following hypothesis was formulated:

$\mathbf{H}_{5}$ : Attitude has a significant influence on consumers' intention to shop online.

\section{Research methods and design Study design and sample}

A quantitative research methodology using a survey data collection research method was regarded as the most appropriate method for the study. Prior online shopping studies adopted a survey to determine factors influencing online shopping of products (Orubu 2016; Tandon et al. 2018). The purpose for adopting a survey was to determine the risk factors influencing consumers' attitudes when shopping online and to determine the influence of consumers' demographic factors on online shopping.

The population targeted for this research was consumers in South Africa comprising of those who either have shopped or have not shopped online. The sample population for the study was shoppers in South Africa, who visited two malls: Cresta Shopping Centre, in Johannesburg and Sunnypark Shopping Centre, in Sunnyside, Pretoria, regardless of whether they have access to internet or not. The study adopted a convenience, non-probability sampling method.

\section{Data collection and research instrument}

The questionnaire items of prior research studies were used to design a questionnaire instrument to achieve the objectives of this study (Yang \& Lester 2004). The questionnaire consisted of 13 demographic questions and 21 statements linked to risk factors influencing consumers when shopping online. The product risk factor was measured using seven risk statements with five statements measuring privacy risk, another five statements measuring delivery risk and four statements measuring security risk. There were four statements linked to attitude towards online shopping and another four statements measuring intention to shop online. Risk factors in online shopping were measured using the Likert scale, from 1 to 5 - with 1 measuring 'highly disagree' and 5 measuring 'highly agree'.

Data were collected from consumers at the two shopping malls from March 2019 to April 2019. Shoppers, who visited the malls during this period, were intercepted by fieldworkers and were asked to participate in the research study by voluntarily completing the self-completion questionnaire provided as a hard copy. A company specialising in fieldwork services was hired to render the services and was responsible for training the fieldworkers prior to data collection. There was no compensation offered to consumers who completed the questionnaires. The questionnaire was ethically approved by the academic institution prior to data collection. It took $20 \mathrm{~min}$ for consumers to complete the questionnaire. A total of 207 people responded, culminating in a response rate of $98 \%$, which is a high response rate. Similar studies investigating risks in online shopping targeted 200 respondents (Hong et al. 2016; Mudaa, Mohd \& Hassan 2016).

\section{Analysis of data}

The SAS JMP version 15 for Mac and the R language version 3.5.2 were used to analyse data. The following statistical tests were conducted to achieve the objectives of the study: descriptive analyses, exploratory factor analysis and structural equation modelling (SEM).

\section{Ethical considerations}

Approval for the study was obtained from the Department of Marketing and Retail Management Ethics Committee, University of South Africa (MRM_2019_001).

\section{Results and findings}

This section will present the results of the study starting with the profile of respondents.

\section{The respondents' profile}

The respondents consisted of more females $(60.4 \%, n=125)$ than males $(39.6 \%, n=82)$. Almost one-third of the respondents were 18-21 years old $(31.6 \%, n=65)$, with almost two-thirds of them being 18-25 years old (60.2\%, 
$n=124)$. Respondents older than 45 years were not well represented in the sample. Less than $10 \%(9.2 \%, n=19)$ of the respondents did not complete Grade 12 . Over $90 \%$ of the respondents $(n=188)$ completed Grade 12 and more than half $(56.6 \%, n=117)$ of the respondents have some tertiary qualification. Most of the respondents $(70.9 \%, n=146)$ have a monthly income of below $\$ 666.66$ (R10 000.00).

All the respondents $(100 \%, n=207)$ had access to the internet with three-quarters $(74.9 \%, n=155)$ purchasing products or services online whilst a quarter $25(25 \%, n=52)$ of respondents do not buy products or services online. More than $90 \%$ $(93.7 \%, n=194)$ of the respondents use their cellphones to access the internet. The more popular method for connecting to the internet is from a computer at home $(45.9 \%, n=95)$. More than $70 \%(72.8 \%, n=150)$ of the respondents use the internet for communication, social websites, etc. The more popular reason for accessing the internet is finding information $(57.3 \%, n=118)$, followed by research, homework and study $(48.1 \%, n=99)$.

Most of the respondents $(83.1 \%, n=172)$ possess a credit and/or debit card and buy clothing and accessories online $(61.1 \%, n=118)$. The next most popular type of purchase is books $(32.6 \%, n=63)$, followed by electronic goods $(30.6 \%$, $n=59)$. Almost $60 \%(58.5 \%, n=121)$ of the respondents do not buy electronic products online. Of those respondents who do not buy electronic goods online, almost one-third $(32.5 \%, n=40)$ indicated that they may buy electronic goods online in the next 12 months. Of those respondents that currently buy electronic goods online, more than $40 \%$
(43.2 $n=38)$ do so once a year. Of those respondents who currently buy electronic goods online, $36.8 \%(n=75)$ visit one to three online stores, before making their purchase. Takealot is the most popular online shop to purchase electronic goods $(70.4 \%, n=119)$, followed by Makro $(38.5 \%, n=65)$.

\section{Factor analysis}

The purpose for conducting the factor analysis was to determine whether variables developed from a literature review could, in fact, be grouped into meaningful variables describing the risk factors influencing consumer intention to shop online. Therefore, the exploratory factor analysis was applied to responses on the 21 risk items with the intention to group risk items into meaningful groups of risk items. To extract the risk factors, the principal axis factoring was used, followed by a quartimin (oblique) rotation. Five of the factors had eigenvalues greater than 1 . For the five-factor solution, the 5 th factor showed three items with between 0.3 and 0.38 factor loadings, which were too low; therefore, the fourfactor solution was considered. The total variance for the combined four factors accounted for $56 \%$. The factor loadings for each scale item are presented (Table 2).

Although items with factor loadings of 0.3 can be accepted (Hair et al. 2010:117), Stevens in Field and Miles (2010:557), recommended a factor loading of 0.364 for a sample of 200 . For this study, items loading 0.40 or greater were considered for further analysis. Four items were dropped because of either loading lower than 0.40 or cross loading, thus retaining 17 items as shown (Table 2). The first factor therefore loaded seven items and was named 'product risk'. The mean score for product risk is 2.166 - standard deviation (SD) of 0.828 ,

TABLE 2: Factor analysis and communalities.

\begin{tabular}{|c|c|c|c|c|}
\hline \multirow[t]{2}{*}{ Risk factors } & \multicolumn{4}{|c|}{ Factor loadings } \\
\hline & Product risk & Privacy risk & Delivery risk & Security risk \\
\hline The product might not be the same as advertised. & 0.87 & - & - & - \\
\hline When shopping online, there is a risk of the product malfunctioning when delivered. & 0.76 & - & - & - \\
\hline The quality of the product might not be the exact specified quality of a product that I purchased. & 0.72 & - & - & - \\
\hline The description of the product might be incorrect. & 0.69 & - & - & - \\
\hline Online shopping is risky, because I cannot examine the product. & 0.68 & - & - & - \\
\hline I fear my product may get damaged during the delivery process. & 0.44 & - & - & - \\
\hline I am comfortable with providing my personal information when shopping online. & - & 0.77 & - & - \\
\hline I feel safe to use an online payment method when shopping online. & - & 0.69 & - & - \\
\hline I trust online shops. & - & 0.66 & - & - \\
\hline Online shopping may affect the image of people around me. & - & - & 0.70 & - \\
\hline The product may be disapproved by my family. & - & - & 0.67 & - \\
\hline It may be difficult to find the right product online. & - & - & 0.56 & - \\
\hline My personal information may be misused if I shop online. & - & - & - & 0.47 \\
\hline I need to feel secure with using the website, before I will use it for online shopping. & - & - & - & 0.43 \\
\hline Policies related to product purchases and returns are stated on the online websites. & - & - & - & 0.41 \\
\hline Cronbach's alpha = 0.96 & 0.88 & 0.78 & 0.74 & 0.42 \\
\hline Mean scores & 2.166 & 3.119 & 3.051 & 2.151 \\
\hline Standard deviation & 0.828 & 0.994 & 0.880 & 0.741 \\
\hline Percentage of variance & 27.561 & 13.229 & 9.308 & 5.719 \\
\hline Eigenvalues & 5.788 & 2.778 & 1.955 & 1.20 \\
\hline Cumulative percentage & 27.561 & 40.791 & 50.099 & 55.818 \\
\hline
\end{tabular}

Note: Loadings below 0.3 were not shown. Factor loadings in bold are 0.4 and above and are considered acceptable for the study. 
lower than for other risk factors, which shows that product risk is of less importance for consumers when shopping online. The SD for 0.828 for this factor shows that the respondents varied in their perception of the product factor having less importance on consumers when shopping online. The second factor loaded three items and was named 'privacy risk'. Loaded on the third factor were four items named 'delivery risk' and the fourth factor was named 'security risk' with three items loading on the factor. The privacy risk and delivery risk had high mean scores of $3.11(\mathrm{SD}=0.994)$ and 3.05 (SD = 0.880), respectively, which implied that these risks are more important to consumers when shopping online; however, the SD for all were high at 0.99 and 0.88 , respectively, showing variation in the respondents' perceptions of these risks factor in online shopping environment. According to Field and Miles (2010:37), the SD closer to 1 indicates that there is variation in the response.

The exploratory principal factor analysis with axis factoring was carried out in SAS JMP version 15, which is considered appropriate for the correlation patterns between the questions used to determine the respondents' perceptions towards online shopping risks in South Africa. The Pearson's product-moment correlation coefficient was used to determine the factorability of the correlation matrix. The assumptions of normality, linearity and homoscedasticity were not violated as indicated by the preliminary distribution analyses. The correlation matrix demonstrated several coefficients of 0.3 and above.

According to Yayar and Karaca (2017:55), the Kaiser-MeyerOlkin (KMO) value must be 0.6 or more. The $\mathrm{KMO}$ value for the study was 0.846 and satisfactory, which indicated that data were suitable for factor analysis. This was also supported by the Bartlett's test of sphericity, which reached statistical significance, $p<0.0001$, then, the correlation matrix was deemed factorable. According to Hair et al. (2010:463), small values of less than 0.05 of the significance level indicate that a factor analysis is useful with the data.

\section{Validity and reliability}

To determine if the individual questions load onto the constructs as intended in the questionnaire and to determine the construct validity of the study, the exploratory factor analysis was performed. According to Child (2006), a threshold minimum of 0.2 must be maintained on the communalities to further determine the construct validity of the instrument, which was performed in this study. One of the items (item 21) had a lower communality of 0.11 and was kept as part of the validation but was just observed. Table 1 was developed to ensure that both the study and the questionnaire are aligned with existing studies, thus achieving construct validity (see Table 1). To further ensure the validity of the questionnaire, it was also pre-tested with 10 respondents and approved by two academics, experts in the field based on the comments from the respondents and the two academics, several minor modifications of the wording and the question item sequence were performed.
Cronbach's alpha $(\alpha)$ coefficient is calculated to assess the reliability of the different constructs in the questionnaire. The overall $\alpha$ for the constructs was 0.96 and the individual $\alpha$ was 0.88 (product risk), 0.78 (privacy risk), 0.74 (delivery risk) and 0.42 (security risk). According to Malhotra (2010), a Cronbach's alpha coefficient must be above 0.70 to be acceptable and that those less than 0.50 are deemed unacceptable whilst those between 0.50 and 0.69 are considered adequate. The more closer to one the value is, the more acceptable it becomes. However, a Cronbach's alpha of 0.60 is considered acceptable for exploratory study, which implies that the acceptability for Cronbach's alpha differs across types of research study. As this study is not an exploratory study, the Cronbach's alpha for security risk of 0.42 was unacceptable and security risk will, therefore, not be used for further analysis.

\section{Model testing}

The model testing was carried out using the lavaan version 0.6-1 (Rosseel 2012) in R version 3.5.2 ( $\mathrm{R}$ Core Team 2018). A maximum likelihood estimation with robust standard errors (maximum likelihood mean [MLM]), which produce a robust (scaled) test statistic, was used. The MLM chisquare test statistic is also referred to as the Satorra-Bentler chi-square with robust standard errors. The latent factors were standardised, allowing free estimation of all factor loadings - the $\mathrm{R}$ version 3.5.2 with the lavaan library. The purpose of this phase is to assess causative relationships amongst latent constructs (Nusair \& Hua 2010). The measures of model fit of this study were performed using the following indices: chi-square value over degree of freedom, normed fit index (NFI), the incremental fit index (IFI), Tucker Lewis index (TLI), comparative fit index (CFI) and standard root mean residual (root mean square error of approximation [RMSEA]). As a result of security being excluded from further analysis based on an unacceptable Cronbach's alpha, the model tested whether the three risk factors: product, privacy and delivery influence consumer attitude towards online shopping and whether consumer attitude towards online shopping influences their intention to shop online. Therefore, $\mathrm{H} 4$ was not tested further because of low Cronbach's alpha.

The results of model fit testing are shown (Table 3). The goodness-of-fit index (GFI), CFI, TLI, IFI, relative fit index (RFI) and NFI, must be greater than or equal to 0.9 in order to show model fit; however, a value greater than 0.8 can marginally be accepted (Hair et al. 2006). As appears here, the model fit was good with the following indices: a chisquare $(178)=238.69 ; p=0.002$, the relative chi-square $=1.34$, RMSEA of $0.04590 \%$ CI $(0.029,0.059)$, standardised root mean squared residual $(\mathrm{SRMSR})=0.079, \mathrm{CFI}=0.96$ (robust) and TLI of 0.95 (robust). The $90 \%$ confidence interval for the RMSEA statistics ranged from 0.029 to 0.059 , meaning that it is plausible that the population RMSEA statistic might be as low as 0.029 and as high as 0.059 . 
TABLE 3: Model fit indices for path analyses.

\begin{tabular}{|c|c|c|c|c|c|c|c|c|}
\hline Model fit index & $\begin{array}{l}\text { Chi-square } \\
\text { (X2/DF) }\end{array}$ & $\begin{array}{c}\text { GFI } \\
\text { (goodness-of-fit) }\end{array}$ & $\begin{array}{c}\text { CFI } \\
\begin{array}{c}\text { (comparative fit } \\
\text { index) }\end{array}\end{array}$ & $\begin{array}{l}\text { TLI (Tucker- } \\
\text { Lewis index) }\end{array}$ & $\begin{array}{l}\text { IFI (incremental } \\
\text { fit index) }\end{array}$ & $\begin{array}{l}\text { RFI (relative } \\
\text { fit index) }\end{array}$ & $\begin{array}{l}\text { NFI (normed } \\
\text { fit index) }\end{array}$ & $\begin{array}{l}\text { RMSEA root (mean square } \\
\text { error of approximation) }\end{array}$ \\
\hline Value indicator & $238.69 / 178=1.34$ & 0.883 & 0.96 & 0.95 & 0.935 & 0.823 & 0.85 & $0.04590 \% \mathrm{Cl}$ \\
\hline
\end{tabular}

GFI, goodness-of-fit index; CFI, comparative fit index; TLI, Tucker-Lewis index; IFI, incremental fit index; RFI, relative fit Index; NFI, normed fit index; RMSEA, root mean square error of approximation.

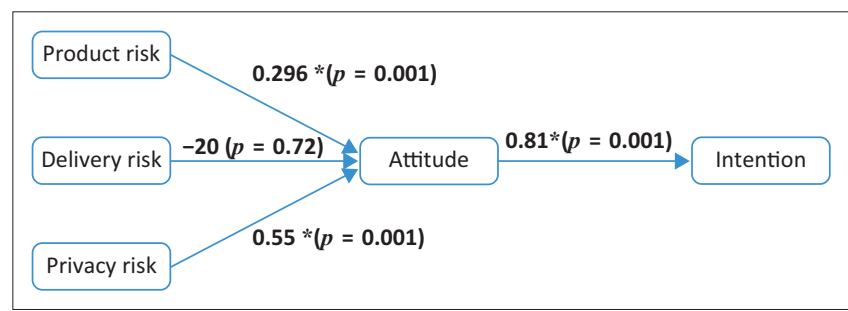

FIGURE 2: Structural model with standardised coefficients.

The RMSEA of 0.045 is less than the required $0.05(<0.05)$, signifying the model fit. An SRMSR of 0.079 was attained in this study. According to $\mathrm{Hu}$ and Bentler (1999), a cut-off value close to 0.08 for standardised root mean residual (SRMR) signifies good fit between the model and the data under observation.

The structural model is shown with standardised coefficients of the three risk factors-product risk, delivery risk and privacy risk that were tested to determine if they influence consumer attitude towards online shopping (Figure 2). The figure also shows the effect of attitude towards consumer intention to shop online.

\section{Hypothesis testing results}

Two regressions were performed as part of the structural part of the SEM model. The first regression tested the influence of privacy, product and delivery risk on attitude towards online shopping and then the second regression tested the effect of attitude on intention to shop online (refer to Table 4 and Table 5).

The $z$-values with Wald tests were used for testing statistical significance in the SEM model. The privacy risk factors have a stronger effect on attitude towards online shopping with a beta coefficient of $0.33(z=3.22)$ followed by product risk with a beta coefficient of $0.24(z=5.43)$. The delivery risk has a negative and weak effect on attitude towards online shopping with a beta coefficient of -0.16 and the $z$ value of -1.79 , which shows that the hypothesis was not significant as shown (Table 3 ). The findings by Thakur and Srivastava (2015) reported that privacy risk weighs lower than product risk with less effect on attitude towards online shopping, which contradict findings of this study.

Attitude has a stronger effect on intention to shop online with a beta coefficient of $0.81(z=7.87)$ (Table 4$)$.

From Table 6, the following hypotheses were supported or rejected:
TABLE 4: Regression Model 1 - Risk factors and attitude.

\begin{tabular}{lccccc}
\hline Attitude & $\begin{array}{c}\text { Beta } \\
\text { coefficient }\end{array}$ & $\begin{array}{c}\text { Standard } \\
\text { error }\end{array}$ & $\boldsymbol{z}$ & $\boldsymbol{p}$ & $\begin{array}{c}\text { Standard } \\
\text { coefficient }\end{array}$ \\
\hline Product risk & 0.341 & 0.106 & 3.221 & 0.001 & 0.296 \\
Privacy risk & 0.544 & 0.100 & 5.439 & 0.000 & 0.553 \\
Delivery risk & -0.221 & 0.123 & -1.798 & 0.072 & -0.203 \\
\hline
\end{tabular}

TABLE 5: Regression Model 2 - Effect of attitude on intention.

\begin{tabular}{lccccc}
\hline Intention & $\begin{array}{c}\text { Standardised } \\
\text { coefficient }\end{array}$ & $\begin{array}{c}\text { Standard } \\
\text { error }\end{array}$ & $z$ & $p$ & $\begin{array}{c}\text { Standard } \\
\text { coefficient }\end{array}$ \\
\hline Attitude & 0.743 & 0.094 & 7.878 & 0.000 & 0.810 \\
\hline
\end{tabular}

- Product risk has a statistically significant influence on users' perceived attitude (standardised coefficient $=0.296$, $p=0.001$ ) (refer to Table 4 and Table 6). The path coefficient of $H_{1}$ (product risk influences attitude towards online shopping) is 0.296 . This shows the effect that product risk has on attitude towards online shopping. The $p$-value of 0.001 signifies that the hypothesis is supported. The findings of this study are similar to those of existing studies that reported that product risk is a barrier to consumers' online shopping (Panwar 2018:2489). However, other studies found product risk to have no significant influence on online shopping (Bhatti et al. 2018:7; Tariq et al. 2016:98), which shows that the influence of product risk on attitude towards online shopping differs across consumers.

- Privacy risk has a statistically significant influence on users' perceived attitude (standardised coefficient $=0.553$, $p<0.001$ ) (refer to Table 4 and Table 6). The path coefficient of $\mathrm{H}_{2}$ (privacy risk influences attitude towards online shopping) is 0.553 . This implies a strong and significant relationship between privacy risk and attitude towards online shopping. The $p$-value 0.001 proves that the hypothesis is supported. According to Orubu (2016:17), perceived privacy risks are major barriers for consumer adoption of online shopping, which support the findings of this study.

- Delivery risk does not have a statistically significant influence on users' attitude towards online shopping (standardised coefficient $=-0.203, p=0.07$ ). The path coefficient of $\mathrm{H}_{3}$ (delivery risk influences attitude towards online shopping) is -0.203 . This indicates that the delivery risk has no influence on attitude towards online shopping. The $p$-value 0.072 signifies that the hypothesis is not supported. The results of the study by Panwar (2018:2489) supported that delivery risk does not have a significant impact on consumers' attitude towards online shopping.

- As a result of the Cronbach's alpha measuring the reliability for the security risk being low, $\mathrm{H}_{4}$ was not tested further.

- Attitude has a statistically significant influence on users' perceived intention (standardised coefficient $=0.81, p<$ 0.001) as shown (Table 5 and Table 6). The path coefficient 
TABLE 6: Hypothesis testing results.

\begin{tabular}{|c|c|c|c|c|}
\hline Hypothesis relationship & Hypothesis & Path coefficient & $p$ & Outcomes \\
\hline H1: Product risk has a significant positive influence on consumers' attitude. & $\mathrm{H}_{1}$ & 0.296 & 0.001 & Supported \\
\hline H2: Delivery risk has a significant positive influence on consumers' attitude. & $\mathrm{H}_{2}$ & 0.553 & 0.001 & Supported \\
\hline H3: Privacy risk has a significant positive influence on consumers' attitude. & $\mathrm{H}_{3}$ & -0.203 & 0.072 & Rejected \\
\hline H4: Security risk has a significant influence on consumers' attitude. & $\mathrm{H}_{4}^{\dagger}$ & - & - & - \\
\hline $\begin{array}{l}\text { Attitude has a statistically significant influence on users' perceived intention } \\
\text { (standardised coefficient). }\end{array}$ & $\mathrm{H}_{5}$ & 0.81 & 0.001 & Supported \\
\hline
\end{tabular}

$\dagger$, Hypothesis was not tested further because of low reliability, Cronbach's alpha.

of $H_{5}$ (attitude has a statistically significant influence on users' intention) is 0.81 , which denotes a strong relationship between attitude towards online shopping and intention to shop online. The $p$-value has a 0.001 confidence level $(p<0.05)$, which signifies that the hypothesis is supported because it is significant. This implies that attitude influences consumers' intention to shop online, which is supported by Lin et al. (2018:1198).

\section{Managerial implications}

The findings of this study contribute to existing research on online shopping in South Africa. The findings confirm that some risk factors play a significant role in the online shopping environment by influencing consumers' attitude towards online shopping. It is important for policymakers and retailers to understand the risks and how they influence consumer's attitude towards online shopping. The implication for policymakers is that they must formulate policies that can help reduce the impact of the risks to increase online shopping adoption in South Africa. There are still a large number of consumers in South Africa who do not shop online; therefore, policymakers could also provide the necessary support to retailers selling online to ensure that risks in online shopping are minimised. Retailers should also find ways to minimise the impact of risks on consumers who are shopping online and more importantly protecting their online shopping activities.

The privacy risk was found to have influence on online shopping than the product factors. This implies that online retailers and markets must address these risk factors if they want to increase the number of people shopping online. For example, with privacy risk, consumers are not comfortable providing personal information. Consumers' personal information may include information about their debit or credit card details. Some online shops allow consumers to pay cash on delivery, which helps to overcome the fear of using debit or credit facilities online; this helps to reduce the privacy risk because consumers do not have to share debit or credit card details. Alternatively, e-tailers and marketers should constantly update the existing security measures in place to ensure that consumers' personal information does not end up in the wrong hands.

Delivery risk was found to have no influence on online shopping. However, retailers should still address this risk to ensure that consumers are happy with the delivery of products when shopping online.
To address the product risk, e-tailers and marketers could use advanced technologies that enable consumers to view or even to try products online, to avoid buying something that will not fit or look different to what they saw online. Online shops such as Spec Savers allow consumers to fit spectacles online before deciding whether to buy or not. This involves the use of augmented reality (AR) shopping. Augmented reality is defined as mixed reality systems that integrate and enhance virtual objects to real physical environments (Yuen, Yaoyuneyong \& Johnson 2011). The systems provide consumers with the ability to navigate through rooms with staged furniture, in houses that are under construction, fit clothing and try on pairs of sunglasses, virtually, in the comfort of their own homes (Hilken et al. 2017:885); therefore, eliminating uncertainties during the purchasing process (Yuen et al. 2011).

Online marketers and e-tailers must still make sure that the product consumers buy are what they receive. They could make sure that the product performs as promised. In addition, they must make it easy for consumers to return products that are not functioning as expected.

\section{Conclusions, limitations and recommendations for further study}

This study found that product risk and privacy risk influence attitude towards online shopping. The delivery risk was found not to have influence on attitude towards online shopping. The study also found that attitude towards online shopping also influences the intention to shop online. Retailers in South Africa can learn from the results of this study and formulate appropriate retail and marketing strategies to manage the risks in online shopping.

The study targeted consumers in Gauteng, at the two malls in Pretoria and Johannesburg. The results cannot be generalised across cities and other areas in South Africa, which serve as a limitation for this study. Another limitation for the study is that fewer respondents $(25 \%, n=52)$ had not shopped online, future studies could investigate risk factors influencing those who do not shop online. Further studies could investigate online shoppers across South Africa and those outside our borders. Studies could also investigate the additional security risk factors because the factor was proven unreliable in this study. Adding more items on security factors could help researchers explore further if security as a factor could load 
satisfactorily and be reliable. The use of AR as a tool for reducing the impact of risk factors on online shopping could also be investigated. Studies could also investigate emerging consumers in South Africa, to determine if they have adopted online shopping and factors that influence them to shop online.

\section{Acknowledgements}

This article is based on the data collected for a Master's dissertation with permission from Miss A. Nhlapulo with permission at the University of South Africa, 2020, titled: 'Factors influencing consumers' behaviour towards online shopping for consumer electronics in Gauteng, South Africa', available here: http:/ /hdl.handle.net/10500/27356.

\section{Competing interests}

The authors declare that they have no financial or personal relationships that may have inappropriately influenced them in writing this article.

\section{Authors' contributions}

K.M.N. wrote literature sections. K.M.M. conceptualised the idea, asked permission to use data from a masters' graduate from the University of South Africa. K.M.M. also mentored K.M.N. and also wrote the empirical part of the article.

\section{Funding information}

This research received no specific grant from any funding agency in the public, commercial or not-for-profit sectors.

\section{Data availability}

Data are available on request from the corresponding author.

\section{Disclaimer}

The views and opinions expressed in this article are those of the authors and do not necessarily reflect the official policy or position of any affiliated agency of the authors.

\section{References}

Aghekyan-Simonian, M., Forsythe, S., Kwon, W.S. \& Chattaraman, V., 2012 'The role of product brand image and online store image on perceived risks and online purchase intentions for apparel', Journal of Retailing and Consumer Services 19(3), 325-331. https://doi.org/10.1016/j.jretconser 2012.03.006

Ariff, M.S.M., Sylvester, M., Zakuan, N., Ismail, K. \& Ali, K.M., 2014, 'Consumer perceived risk, attitude and online shopping behaviour; empirical evidence from Malaysia', IOP Conference Series: Materials Science and Engineering 58(1), 29-31. https://doi.org/10.1088/1757-899X/58/1/012007

Ariffin, H., Mohan, T. \& Goh, Y., 2018, 'Influence of consumers' perceived risk on consumers' online purchase intention', Journal of Research in Interactive Marketing 12(3), 309-327. https://doi.org/10.1108/JRIM-11-2017-0100

Arora, N. \& Rahul, M., 2018, 'The role of perceived risk in influencing online shopping attitude among women in India', International Journal of Public Sector Performance Management 4(1), 98-113.

Arora, S. \& Sahney, S., 2018, 'Consumer's webrooming conduct: An explanation using the theory of planned behavior', Asia Pacific Journal of Marketing and Logistics 30(4), 1040-1063. https://doi.org/10.1504/IJPSPM.2018.088697
Bhatti, A., Saad, S. \& Gbadebo, S.M., 2018, 'Convenience risk, product risk, and perceived risk influence on online shopping: Moderating effect of attitude', Science Arena Publications International Journal of Business Management 3(2), Science

Businesstech, 2018, South Africans are expected to spend R45 billion shopping online this year, viewed 20 December 2019, from https://businesstech.co.za/news/ internet/269645/south-africans-are-expected-to-spend-r45-billion-shoppingonline-this-year.

Chang, M.-L. \& Wu, W.-Y., 2012, 'Revisiting perceived risk in the context of online shopping: An alternative perspective of decision-making styles', Psychology \& Marketing 29(5), 378-400. https://doi.org/10.1002/mar.20528

Child, D., 2006, The essentials of factor analysis, 3rd edn., Continuum, New York, NY.

Dai, H. \& Chen, Y., 2015, 'Effects of exchange benefits, security concerns and situational privacy concerns on mobile commerce adoption', Journal of International Technology and Information Management 24(3), 41-56.

Export.gov., 2018. South Africa - ECommerce / export.gov, viewed 19 December 2019, from https://www.export.gov/article?id=South-Africa-ecommerce.

Farhana N, Khan, T. \& Noor, S., 2017, 'Factors affecting the attitude towards online shopping: An empirical study on urban youth in Bangladesh', Australian Academy of Business and Economics Review 3(4), 224-234.

Field, A. \& Miles, J., 2010, Discovering statistics using SAS, Sage Publications, Richmond.

Forsythe, S. \& Shi, B., 2003, 'Consumer patronage and risk perceptions in Internet shopping', Journal of Business Research 56(11), 867-876. https://doi.org/10.1016/ S0148-2963(01)00273-9

Fortes, N. \& Rita, P, 2016, 'Privacy concerns and online purchasing behaviour: Towards an integrated model', European Research on Management and Business Economics 22(3), 167-176. https://doi.org/10.1016/j.iedeen.2016.04.002

Hair, J.F., Black., W.C., Babin., B.J., Anderson., R.E. \& Tatham, R.L., 2006, Multivariant data analysis, Pearson International Edition, New Jersey.

Hilken, T., De Ruyter, K., Chylinski, M., Mahr, D. \& Keeling, D.I., 2017, 'Augmenting the eye of the beholder: Exploring the strategic potential of augmented reality to enhance online service experiences', Journal of the Academy of Marketing Science 45(6), 884-905. https://doi.org/10.1007/s11747-017-0541-x

Hong, L.M., Zulkiffli, W.F.W. \& Hamsani, N.H., 2016, 'The impact of perceived risks towards customer attitude in online shopping', International Journal 1(2), 13-21.

Hsu, S.H. \& Luan, P.M., 2017, 'The perception risk of online shopping impacted on the consumer's attitude and purchase intention in Hanoi, Vietnam', Journal of Business \& Economic Policy 4(4), 19-29.

$\mathrm{Hu}$, L., \& Bentler, P.M., 1999, 'Cutoff criteria for fit indexes in covariance structure analysis: Conventional criteria versus new alternatives', Structural Equation Modeling: A Multidisciplinary Journal 6:1, 1-55. https://doi.org/10.1080/10705519909540118

Hu, L., Peter, M. \& Bentler, P., 1999, 'Cut-off criteria for fit indexes in covariance structure analysis: Conventional criteria versus new alternatives', Structura Equation Modelling 6(1), 1-55. https://doi.org/10.1080/10705519909540118

Itnewsafrica, 2017, Mobile shopping in South Africa, viewed 18 December 2019, from https://www.itnewsafrica.com/2017/06/mobile-shopping-in-southafrica.

Jun, G. \& Jaafar, N.I., 2011, 'A study on consumers' attitude towards online shopping in China', International Journal of Business and Social Science 2(22), 122-132.

Keisidou, E., Sarigiannidis, L. \& Maditinos, D., 2011, 'Consumer characteristics and their effect on accepting online shopping, in the context of different product types', International Journal of Business Science \& Applied Management (IJBSAM) 6(2), 31-51.

Kukar-Kinney, M. \& Close, A.G., 2010, 'The determinants of consumers' online shopping cart abandonment', Journal of the Academy of Marketing Science 38(2), 240-250. https://doi.org/10.1007/s11747-009-0141-5

Lin, X., Featherman, M., Stoney, L., Brooks, L.L. \& Hajli, N., 2019, 'Exploring gender differences in online consumer purchase decision making: An online product presentation perspective', Information Systems Frontiers 21, 1187-1201. https:// doi.org/10.1007/s10796-018-9831-1

Malapane, T.A., 2019, 'A risk analysis of e-commerce: A case of South African online shopping space', in 2019 Systems and Information Engineering Design Symposium (SIEDS), Charlottesville, VA, 13 June 2019, pp. 1-6. https://doi.org/10.1109/ SIEDS.2019.8735643

Malhotra, N.K., 2010, Marketing research: An applied orientation, 6th edn., Pearson Prentice-Hall, New Jersey.

Marza, S., Idris, I. \& Abror, A., 2019, The influence of convenience, enjoyment, perceived risk, and trust on the attitude toward online shopping, Proceedings of the 2nd Padang International Conference on Education, Economics, Business and Accounting (PICEEBA-2 2018), Advances in Economics, Business and Management Research, vol. 64, West Sumatera, Indonesia, November 24-25, Management Research
2018, pp. 588-597.

Masoud, E.Y., 2013, 'The effect of perceived risk on online shopping in Jordan', European Journal of Business and Management 5(6), 76-87.

Nawi, N.C., Mamun, A.A., Hamsani, N.H.B. \& Muhayiddin, M.N.B., 2019, 'Effect of consumer demographics and risk factors on online purchase behaviour in Malaysia', Societies 9(1), 10. https://doi.org/10.3390/soc9010010

Nusair, K. \& Hua, N., 2010, 'Comparative assessment of structural equation modeling and multiple regression research methodologies: E-commerce context', Tourism Management 31(3), 314-324. https://doi.org/10.1016/j.tourman.2009.03.010

Orubu, O.F., 2016, 'The impact of perceived risk on willingness to buy in online markets', E3 Journal of Business Management and Economics 7(1), 13-18. https:// doi.org/10.18685/EJBME(7)1_EJBME-15-020 
Panwar, C., 2018, 'Consumer perceived risk in online shopping environment via Facebook as medium', International Journal of Engineering \& Technology 7(4) 2485-2490. https://doi.org/10.14419/ijet.v7i2.18.11017

Pappas, N., 2016, 'Marketing strategies, perceived risks, and consumer trust in online buying behaviour', Journal of Retailing and Consumer Services 29, 92-103. https://doi.org/10.1016/j.jretconser.2015.11.007

Pathak, V.K. \& Pathak, A., 2017, 'Understanding perceived risk: A case study of green electronic consumer products', Management Insight 13(1), 33-37. https://doi. org/10.21844/mijia.v13i01.8367

PayFast, 2019, How to take advantage of 2019 e-commerce trends, viewed 18 December 2019, from https://www.payfast.co.za/2019/03/11/how-to-takeadvantage-of-2019-e-commerce-trends.

Pi, S.M. \& Sangruang, J., 2011, 'The perceived risks of online shopping in Taiwan' Social Behavior and Personality 39(2), 275-286. https://doi.org/10.2224/ sbp.2011.39.2.275

R Core Team., 2018, 'R: A language and environment for statistical computing. R Foundation for Statistical Computing, Vienna, Austria', viewed 15 May 2021, from URL https://cran.r-project.org/bin/windows/base/old/3.5.2/

Rosillo-Díaz, E., Blanco-Encomienda, F.J. \& Crespo-Almendros, E., 2019, 'A crosscultural analysis of perceived product quality, perceived risk and purchase intention in e-commerce platforms', Journal of Enterprise Information Management 33(1) 139-160. https://doi.org/10.1108/JEIM-06-2019-0150

Rosseel, Y., 2012, 'lavaan: An R Package for Structural Equation Modeling', Journal of Statistical Software 48, 1-36. https://doi.org/10.18637/jss.v048.i02

Smith, C., 2020, How ecommerce is exploding in SA, viewed 13 February 2020, from https://www.fin24.com/Economy/how-ecommerce-is-exploding-in-sa-20180316.

Statista, 2018, ECommerce - South Africa / Statista Market Forecast, viewed 18 December 2020, from https://www.statista.com/outlook/243/112/ecommerce/south-africa.
Statista, 2020, Online shopping cart abandonment rate in selected industries in March 2020, viewed 14 May 2021, from https://www.statista.com/statistics/457078/ category-cart-abandonment-rate-worldwide/.

Tanadi, T., Samadi, B. \& Gharleghi, B., 2015, 'The impact of perceived risks and perceived benefits to improve an online intention among generation-Y in Malaysia', Asian Social Science 11(26), 226-238. https://doi.org/10.5539/ass.v11n26p226

Tandon, U., Kiran, R. \& Sah, A., 2018, 'The influence of website functionality, drivers and perceived risk on customer satisfaction in online shopping: An emerging economy case', Information Systems \& e-Business Management 16(1), 57-91. https://doi.org/10.1007/s10257-017-0341-3

Tariq, A., Bashir, B. \& Shad, M.A., 2016, 'Factors affecting online shopping behavior of consumers in Pakistan', Journal of Marketing and Consumer Research 19, 95-100.

Thakur, R. \& Srivastava, M., 2015, 'A study on the impact of consumer risk perception and innovativeness on online shopping in India', International Journal of Retail \& Distribution Management 43(2), 148-166. https://doi.org/10.1108/IJRDM-062013-0128

Wolny, J. \& Charoensuksai, N., 2014, 'Mapping customer journeys in multichannel decision-making', Direct, Data and Digital Marketing Practice 15(4), 317-326. https://doi.org/10.1057/dddmp.2014.24

Yang, B. \& Lester, D., 2004, 'Attitudes toward buying online', Cyberpsychology \& Behaviour 7(1), 85-91. https://doi.org/10.1089/109493104322820156

Yang, J., Sarathy, R. \& Lee, J.K., 2016, 'The effect of product review balance and volume on online shoppers' risk perception and purchase intention', Decision Support Systems 89, 66-76. https://doi.org/10.1016/j.dss.2016.06.009

Yayar, R. \& Karaca, O.E., 2017, 'Economic literacy levels of public officers in Turkey', Pakistan Journal of Commerce and Social Sciences 11(1), 49-65.

Yuen, S., Yaoyuneyong, G. \& Johnson, E, 2011, 'Augmented reality: An overview and five directions for AR in education', Journal of Educational Technology Development and Exchange 4(1), 119-140. https://doi.org/10.18785/jetde.0401.10 